\title{
Application of HEC-HMS Model to Assess Streamflow and Water Resources Availability in Stung Sangker Catchment of Mekong' Tonle Sap Lake Basin in Cambodia
}

\author{
Kimhuy Sok and Chantha Oeurng * \\ Department of Rural Engineering, Institute of Technology of Cambodia, Russian Federation Boulevard, P.O. \\ Box 86 Phnom Penh, Cambodia. \\ * Corresponding Author: chantha@itc.edu.kh
}

\begin{abstract}
Hydrologic studies on rainfall-runoff have been extensively conducted in many regions around the globe to fulfill various desirable needs with a purpose of effective and proper planning and managing water resources for present and future uses, whereas such study is not well drawn much attention to river catchments of Tonle Sap Lake Basin in Cambodia, which may prevail to water insecurity. The Stung Sreng catchment, which is one among them considered to be a significant basin for water resources management in Cambodia, is remarkably increasing under intolerable pressures in water resources development. This study was to apply HEC-HMS (Hydrological Engineering CenterHydrological Model System) model to predict streamflow of Stung Sangker catchment, located in Tonlesap Lake Basin in Cambodia. The result showed that the calibration was good at monthly basis. The model performance was given by Nash-Sutcliffe Efficiency criteria followed by 0.44 for daily and 0.71 for monthly basis, respectively. Moreover, the Percent Bias (PBIAS) for daily and monthly simulation was $4.13 \%$ and $3.56 \%$, indicating a satisfactory model fit. The HEC-HMS conceptual model can be used to simulate flow of Stung Sangke catchment on a continuous time scale particularly monthly basis. The result also indicated that there was a clear seasonal variation in monthly water availability, especially during both wet and dry season.
\end{abstract}

Keywords: HEC-HMS model; streamflow; water availability; rainfall-runoff; Tonle Sap Basin

\section{INTRODUCTION}

Water resources in Cambodia is heavily dependent on water inflows from other countries, receiving $70 \%$ of the water from the Mekong River (ADB, 2014), and despite of the inflow of the Mekong River, Tonle Sap Lake of Cambodia has a big potential water resources for the surrounded sub-basins, which means very significant to Cambodia. Most of these catchments are considered to have abundant water in rainy season. However, these resources were reported to respond to new and serious challenges due to rice exports and knowledge gaps in all development sectors (MOWRAM, 2015), which have clearly demonstrated that water shortage will be occurring and facing due to the increase in water demand for agriculture, domestic uses, commercial and industrial uses, hydropower, the improper management of water resources, the effects of climate change and so on so forth causing to greater food insecurity for millions of people in most regions of the world (Choudhari et al., 2014).

A considerable attention should be captured not only in the operation and management of reservoir and watersheds but also an accurate perception of assessing water availability both in upstream and downstream, especially the development infrastructures within the system in order to deal with water related problems, yet ADB (2014) reported that Cambodia's water 
resources assessment and monitoring are totally inadequate for management, particularly the model for river basin management is not being formalized well. ADB (2014) also detailed that the assessment of water resources in catchments around Tonle Sap Basin has not well conducted yet, which has revealed a lacked comprehension on water resources systems in those river basins with their potential water availability to expand Cambodia's economic mainstay as an agrarian country. Thus, understanding streamflow and water resources availability is the best way to manage water resources, flood and avoid drought during the year. A considerable attention should be captured not only in the operation and management of reservoir and catchments but also an accurate perception of assessing water availability both in upstream and downstream, especially the development infrastructures within the system in order to deal with water related problems, yet ADB (2014) reported that Cambodia's water resources assessment and monitoring are totally inadequate for management. ADB (2014) also detailed that the assessment of water resources in catchments around Tonle Sap Basin has not well conducted yet, which has revealed a lacked comprehension on water resources systems in those river basins with their potential water availability to expand Cambodia's economic mainstay as an agrarian country.

One of the most challenging areas in hydrology is denoted by the availability of data, so comprehensive understanding and accurate prediction of runoff response to precipitation and its discharge to the outlet will be extremely difficult to achieve with constrained or no data (Chu and Steinman, 2009; Halwatura and Najim, 2013; Todini, 1996). Decision support tools can help in better development an approach to this challenge is the use of suitable hydrologic models for the efficient management of watersheds and ecosystems (Yener et al., 2007). The USACE model, Hydrologic Modeling System, is designed to simulate the precipitationrunoff processes of dendritic catchment systems (HEC, 2008). HEC-HMS is widely used in a broad range of hydrologic problems varying from the analysis of large river basin water supply and flood hydrology to the study of small urban or natural catchment runoff. HECHMS has been used for studies of water availability, urban drainage, and flow forecasting, future urbanization impact, reservoir spillway design, flood damage reduction, flood plain regulation, and systems operation (HEC, 2008). The hydrologic Engineering Centers Hydrologic Modeling System (HEC-HMS) which is one among many watershed models supporting both lumped and distributed model (Madsen, 2000) used to simulate rainfallrunoff correlation, has become a popular and reliable hydrologic model due to its capability in short-time simulation, ease to use and the use of common methods (Arekhi, 2012), the less required input parameters, economics, the capacity in runoff simulation in ungauged catchment (Choudhari et al., 2014) and low flow prediction (De Silva et al., 2013). A number of studies have also reported a successful use of HEC-HMS model in generating runoff in different regions and climatic conditions around the globe (Anderson et al., 2002; Fleming and Neary, 2004; Halwatura and Najim, 2013; Majidi and Shahedi, 2012; Yener et al., 2007; Yusop et al., 2007). In order to address the current problems and to better start planning and managing the water resources within the river basin.

Therefore, the main objective of this work is to apply HEC-HMS model for simulating streamflow and to assess water availability of Stung Sangker catchment located in Tonlesap Lake Basin. 


\section{MATERIALS AND METHODS}

\subsection{Study Area}

Stung Sangker basin is one of the catchments in the Tonle Sap Lake Basin Error! Reference source not found. It is located at the latitude and longitude coordinates of N13 $03^{\circ} 07.24^{\prime \prime}$, and E103'17'33.31' ' in Battambang province. Its catchment area is $5540.63 \mathrm{~km}^{2}$. There are 3 available rainfall stations and a discharge station. The annual rainfall is $1183 \mathrm{~mm}$ which the minimum temperature was $22.5^{\circ} \mathrm{C}$ and maximum temperature was $33^{\circ} \mathrm{C}$.

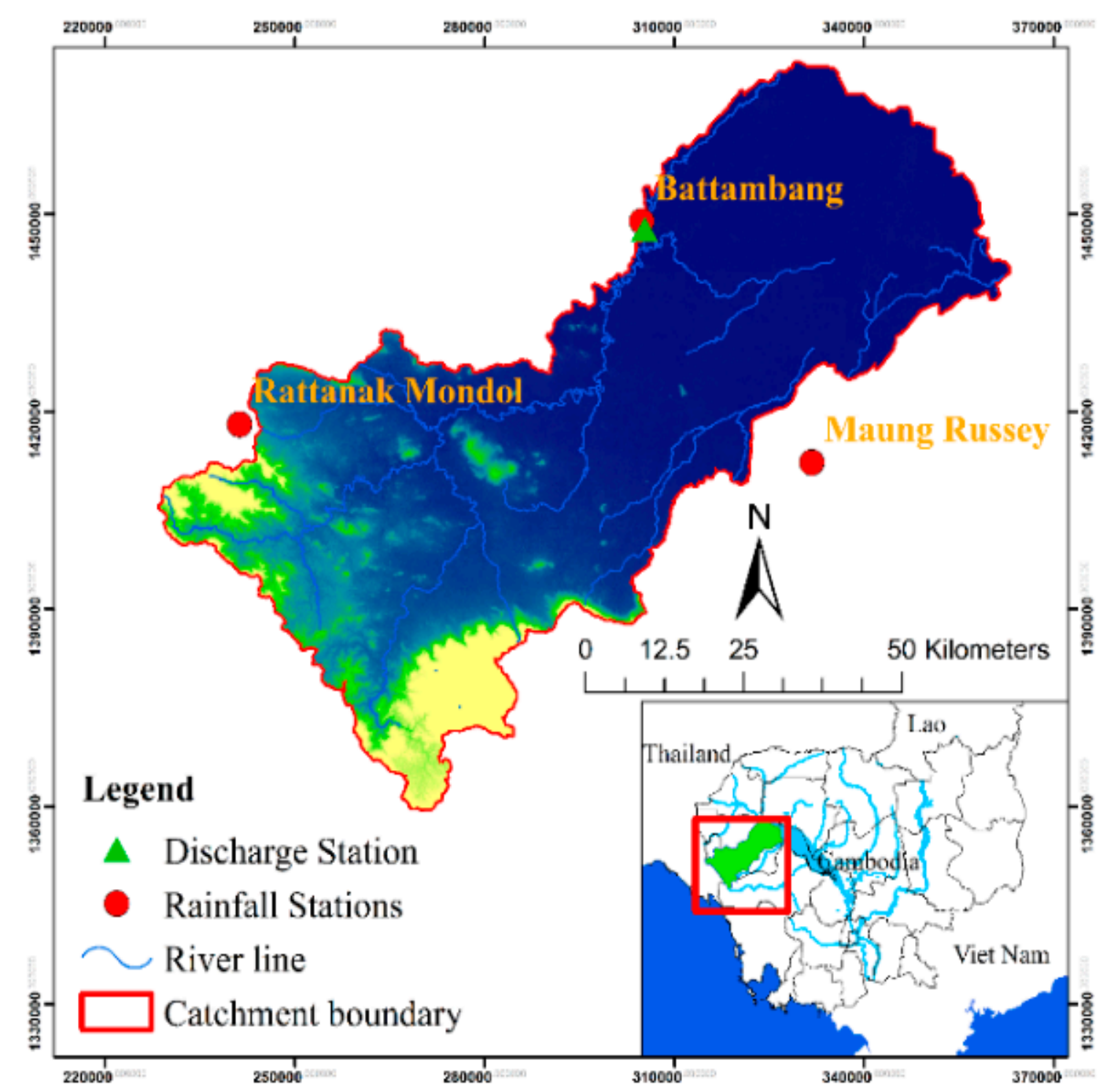

Figure 1. Stung Sangker catchment located in Tonlesap Basin, Cambodia

\subsection{Rainfall, evapotranspiration and runoff datasets}

Three daily rainfall data at station (130305, 120303 and 120202) and an observed discharge data at station (550102) data were obtained from The Ministry of Water Resources and Meteorology (MOWRAM) from 01 January 2000 to 31 December 2006. All of those stations are geographically located at $(13.1,103.2),(12.7706,103.45)$ and $(12.859,102.618)$, respectively. The discharge station is located with daily rainfall station 130305 . On the other hand, weather data such as humidity, solar radiation and temperature are downloaded from SWEAT global database (NCEP, 2015). 1303031 is the ID of the weather station which located at $(12.9575,103.125)$. 


\subsection{Soil types and land cover}

Soil data and land use were obtained from MOWRAM and soil type is classified as four hydrologic soil group: A (Sand, Loamy sand or sandy loam, 0\%), B (Loam or Silt loam, $28.9 \%$ ), C (Sandy clay loam, 31.7\%), D (Clay loam, Silty clay loam, Sandy clay, Silty clay or clay, 39.4\%) (Error! Reference source not found.). On the other hand, Land use data in Stung- Sanger basin indicated that the catchment had agricultural land $19.48 \%$, water features $0.49 \%$, forest cover $44.35 \%$, Build-up area $0.21 \%$, shrub lands $22.6 \%$, and grasslands $12.87 \%$, respectively (Error! Reference source not found.).

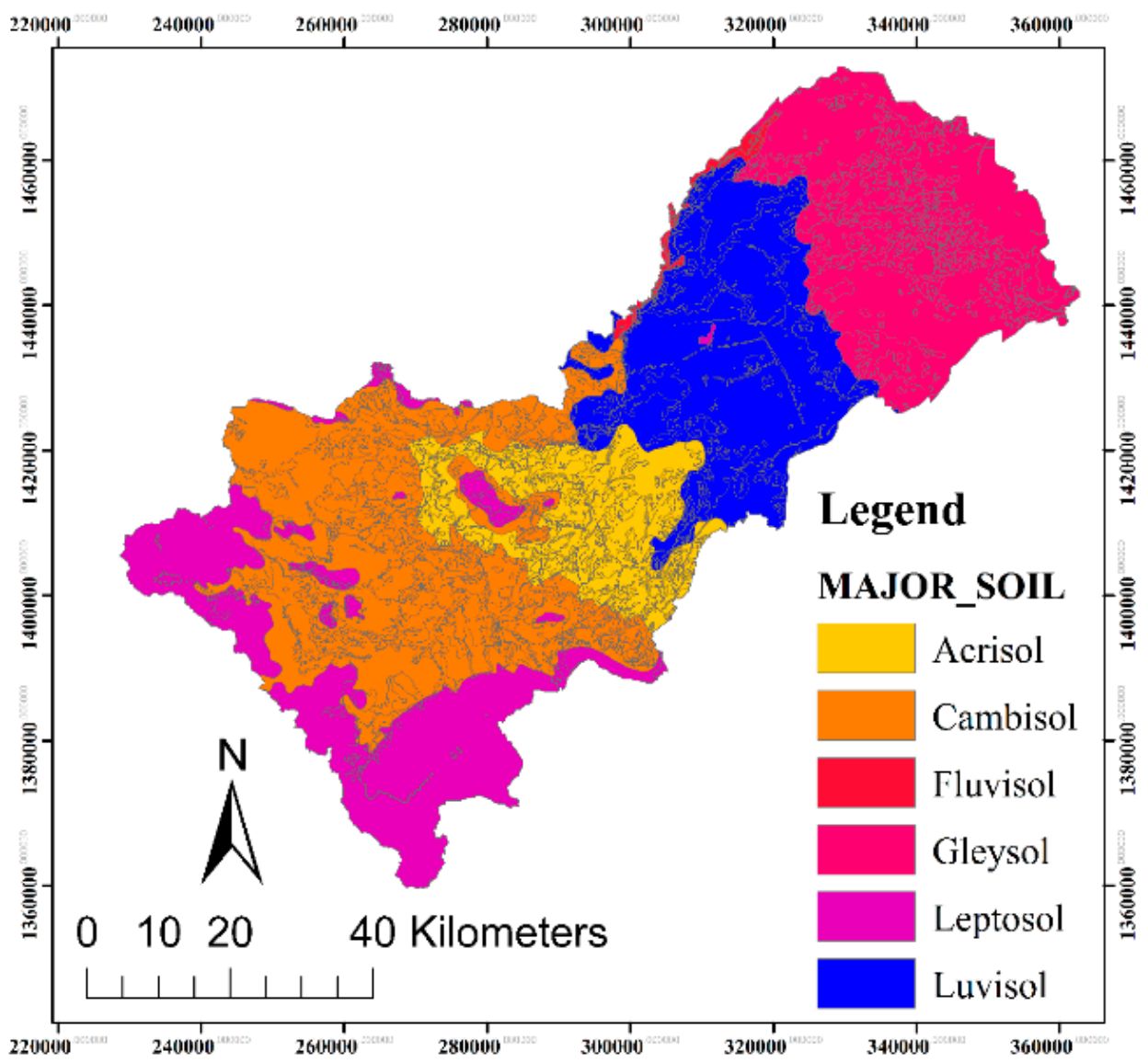

Figure 2. Soil types map of Stung Sangker Catchment 


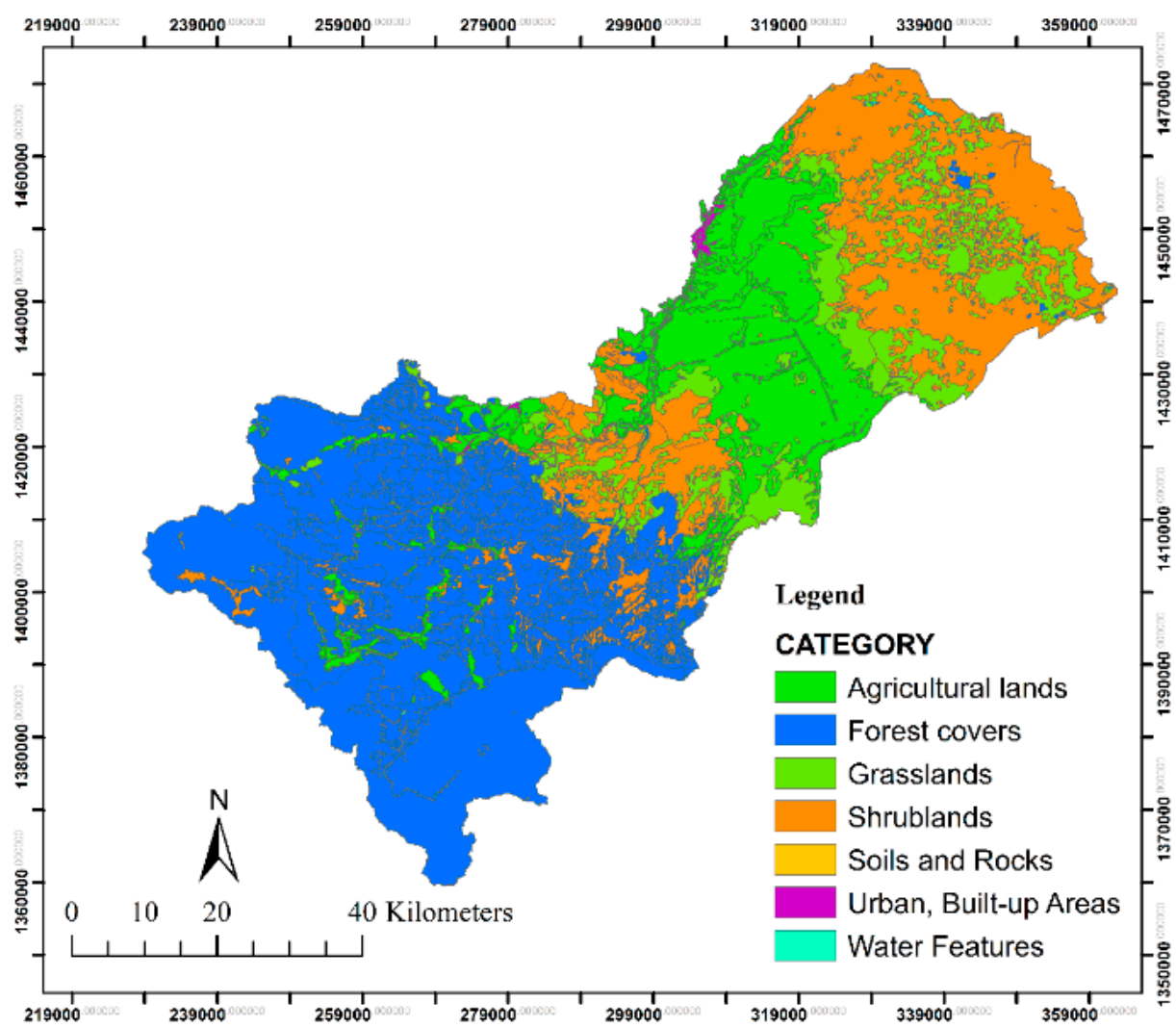

Figure 3. Land Use map of Stung Sangker catchment

\subsection{HEC-HMS model setup}

Four main components which are created for developing a HEC-HMS project are basin model manager, meteorologic model manager, control specifications manager, input data (time series, paired data and gridded data). The Basin model manager for instance, contains the hydrologic elements (Sub-basin, reach, junction, reservoir, diversion, source and sink) and their connectivity that represents the movement of water through the drainage system (Scharffenberg and Fleming, 2006). Control specifications manager are one of the main component of the project, and is principally used to control time interval of simulation. The meteorological component is also the first computational element by means of which precipitation input is spatially and temporally distributed over the river basin. The spatiotemporal precipitation distribution is accomplished by the inverse distance method and evapotranspiration computations were carried out using FAO Penman-Monteith method. Hydrologic model often require time-series of precipitation data for estimating basin-average rainfall. A time-series of flow data, often called observed flow or observed discharge. This main component inputted all the meteorological data such as rainfall, observed discharge, evapotranspiration, wind speed, humidity and sunshine hour. The process of the model is detailed in Error! Reference source not found.. 


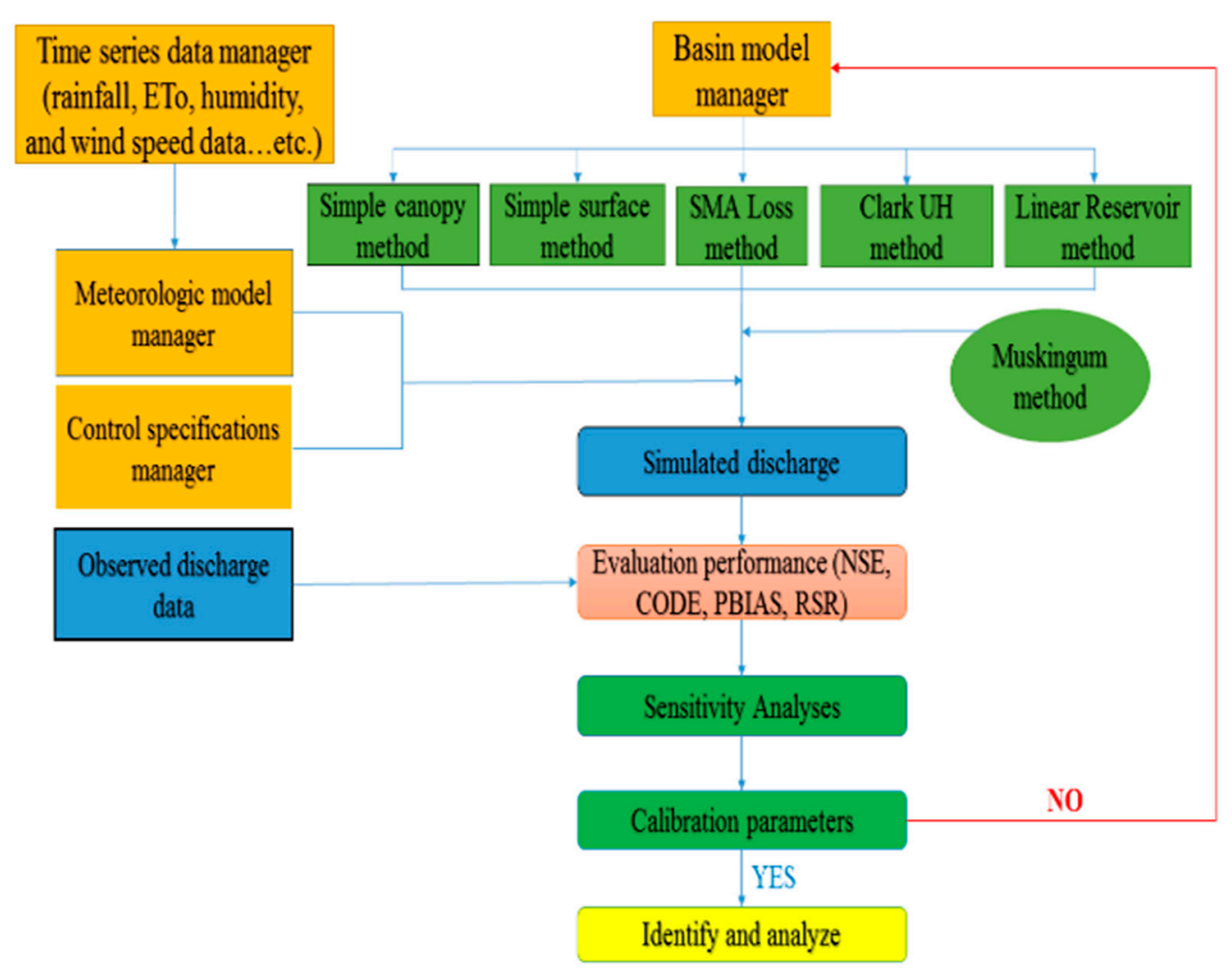

Figure 4. HEC-HMS model flow chart

\subsection{Model theory and approach}

\subsubsection{Loss method}

Simple canopy method is a simple representation of a plant canopy. All precipitation is intercepted until the storage capacity is filled. Once the storage is filled, all further surface is included. The canopy will consume all the potential evapotranspiration until the water in storage has been eliminated. Simple surface method is a simple representation of the soil surface. All precipitation or precipitation through-fall that arrives on the soil surface is captured in storage until the storage capacity of the surface is filled. Water in surface storage infiltration into the soil when even it is present in storage. That is, water will infiltrate even when the storage capacity is filled, and the precipitation through-fall rate exceeds the infiltration rate.

The soil moisture accounting loss method uses three layers to represent the dynamics of water movement in the soil. It is often used in conjunction with a canopy and surface method. Layers within the method include soil storage, upper groundwater, and lower groundwater. The soil layer is subdivide into tension storage and gravity storage. Groundwater layer are not design to represent aquifer processes, they are intended to be used for representing shallow interflow processes. Figure 3 is shown about the process of water movement in SMA method from precipitation.

The Clark Unit Hyetograph is a synthetic unit hydrograph method. This means that the user is not required to develop a unit hydrograph through the analysis of past observed hydrographs. Instead, a time versus area curve (time-area curve) built into the program is used to develop the translation hydrograph resulting from a burst of precipitation. The time 
of concentration $\boldsymbol{T} \boldsymbol{c}$ defines the maximum travel time in the sub-basin. It is used in the development of the translation hydrograph. The equation of the time:

$$
T_{c}=L^{0.8} \frac{\left(S^{\prime}+25.4\right)^{0.7}}{4238 \times S^{0.5}}
$$

(1)

$$
S^{\prime}=\frac{25400}{C N}-254
$$

(2)

$\mathbf{L}$ : flow length (m), $\mathbf{C N}$ : Curve number, $\mathbf{S}$ : average catchment land slop (\%)

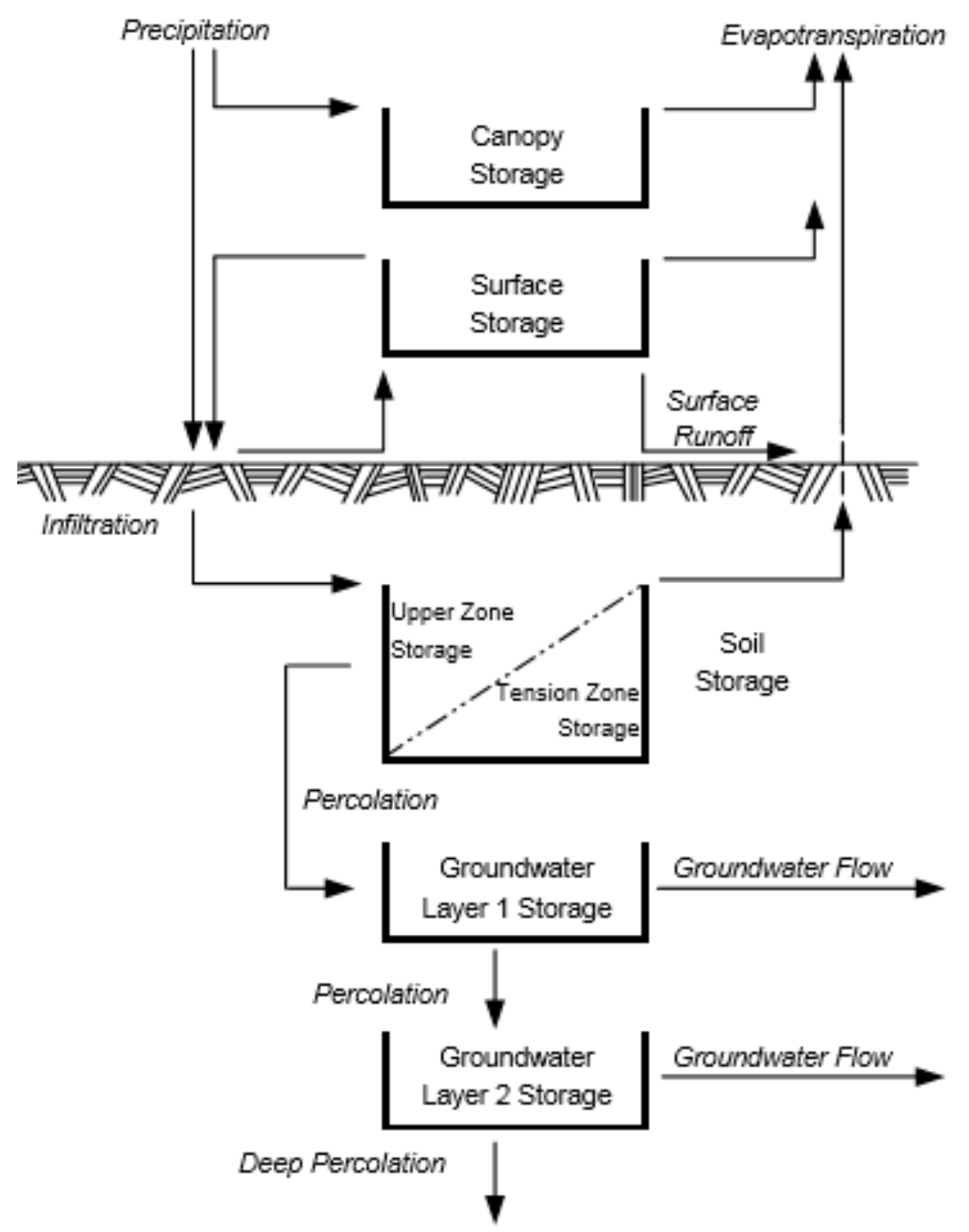

Figure 5. Conceptual Schematic of the Continuous Soil Moisture Accounting Loss Method

\subsubsection{Reservoir Routing}

The linear reservoir base flow method, as its name implies, used a linear reservoir to model the recession of base flow after a storm event. It conserves mass within the sub-basin. Infiltration computed by the loss method is connected as the inflow to the linear reservoir. It can be used with one or two layers. When it is used with the soil moisture accounting or gridded soil moisture accounting methods, the infiltration is connected to the lateral outflow 
of the ground water layers. For all other loss methods, the computed infiltration is separated equally between the two layers defined in the base flow method.

Muskingum method for channel routing is chosen. In this method $\mathrm{X}$ and $\mathrm{K}$ parameters must be evaluated. Theoretically, $\mathrm{K}$ parameter is time of passing of a wave in reach length and $\mathrm{X}$ parameter is constant coefficient that its value varies between $0-0.5$.

\subsubsection{Inverse distance method}

The inverse distance method was originally designed for application in real-time forecasting system. It can use recording gages that report on a regular interval like 15 minutes or 1 hour. It can also use gages that only report daily precipitation totals. Because it was designed for real time forecasting, it has the ability to automatically switch from using close gages to using more distance gages when the closer gages stop reporting data

\subsubsection{Penman Monteith method}

The Penman Monteith method implements the Penman Monteith equations for computing evapotranspiration at less than a daily time interval as detailed by (Allen et al., 1998). The equations are based on a combination of an energy balance with a mass transfer. The maximum possible evapotranspiration is moderated by an aerodynamic resistance due to friction as air flows over the vegetable.

\subsubsection{Statistical evaluation performance parameters}

There are three statistical evaluation performance parameters are selected for evaluation the performance of the HEC-HMS model in Stung Sangker basin such as Percentage Bias (PBIAS) measures the average tendency of the simulated data to be larger or smaller than their observed counterparts (Gupta et al., 1999), Nash-Sutcliff efficiency (NSE) is expressed as one minus the sum of squared differences of the estimated and observed values divided by the variance of the observed values, and RMSE-observations standard deviation ratio (RSR) is calculated as the ratio of the RMSE and standard deviation of measured data. The equations of each parameter are:

$$
\begin{gathered}
P B I A S=\frac{\sum_{i=1}^{n}\left(Q_{i}^{o}-Q_{i}^{e}\right)}{\sum_{i=1}^{n} Q_{i}^{o}} \times 100 \\
N A S E=1-\frac{\sum_{i=1}^{n}\left(Q_{i}^{o}-Q_{i}^{e}\right)^{2}}{\sum_{i=1}^{n}\left(Q_{i}^{o}-Q_{m}^{o}\right)^{2}}
\end{gathered}
$$

$$
R S R=\left(\frac{\sqrt{\sum_{i=1}^{n}\left(Q_{i}^{o}-Q_{i}^{e}\right)^{2}}}{\sqrt{\sum_{i=1}^{n}\left(Q_{i}^{o}-Q_{m}^{o}\right)^{2}}}\right)
$$


Where $Q_{i}^{e}$ and $Q_{i}^{o}$ are the estimated and observed discharges $\left(\mathrm{m}^{3} \mathrm{~s}^{-1}\right)$, respectively; $Q_{m}^{e}$ and $Q_{m}^{o}$ are means of the estimated and observed discharges $\left(\mathrm{m}^{3} \mathrm{~s}^{-1}\right)$, respectively; $n$ is the number of data pairs.

\section{RESULTS AND DESCUSSION}

\subsection{Sensitivity analysis}

Determination of the sensitive parameters is one of the most important tasks in rainfall-runoff modeling in order to reduce the parameters and the time of the calibration. Before, the calibration one parameter at a time was varied an analyses from $-50 \%$ to $50 \%$ with increments of $10 \%$, keeping all other parameters constant, we found that the most sensitive method is soil moisture accounting loss method (SMA) which has 10 parameters for calibrating while the most sensitive parameters in this method are Tension storage, groundwater 2 storage, soil percolation an groundwater 1 coefficient, respectively as shown in the Error! Reference source not found..

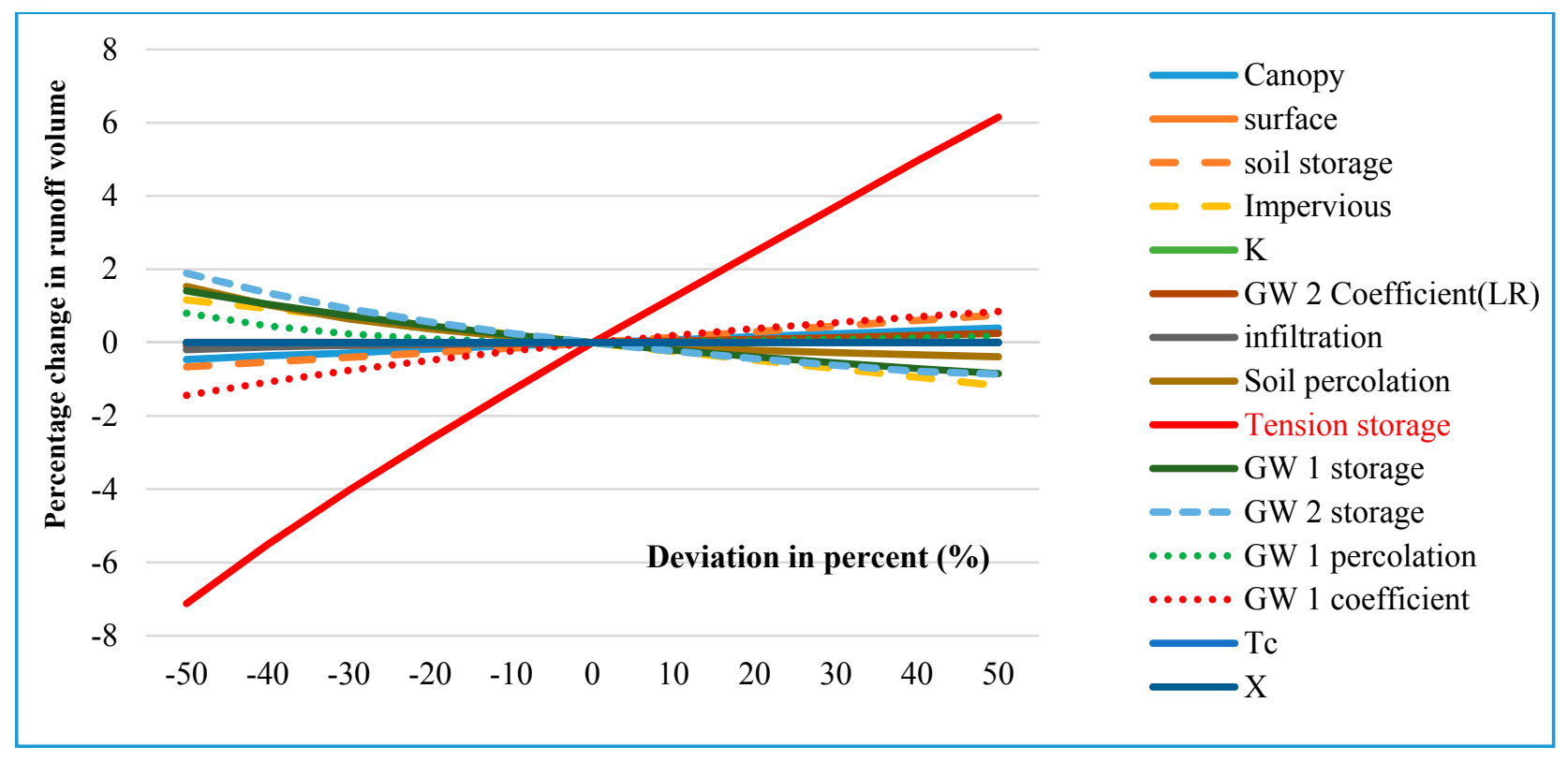

Figure 6. Sensitivity analysis graph of HEC-HMS model

\subsection{Flow simulation}

Error! Reference source not found.7 showed the comparison of daily observed flow from 2000 to 2006 with daily simulated flow. The daily simulation could not well capture the observed flow during peaks in the rainy season. The underestimation could be also attributed to due to various upstream water diversions which were not taken into the model. Moreover, the representative of three rainfall stations for model simulation in this large catchment can add more uncertainties. However, the model simulation at monthly time scale was likely to be improved with the statistical evaluation performance parameters of the monthly time scale. The model performance was given by Nash-Sutcliffe Efficiency criteria followed by 0.44 for daily and 0.71 for monthly basis, respectively. Moreover, the Percent Bias (PBIAS) for daily and monthly simulation was $4.13 \%$ and $3.56 \%$, indicating a satisfactory model fit. 


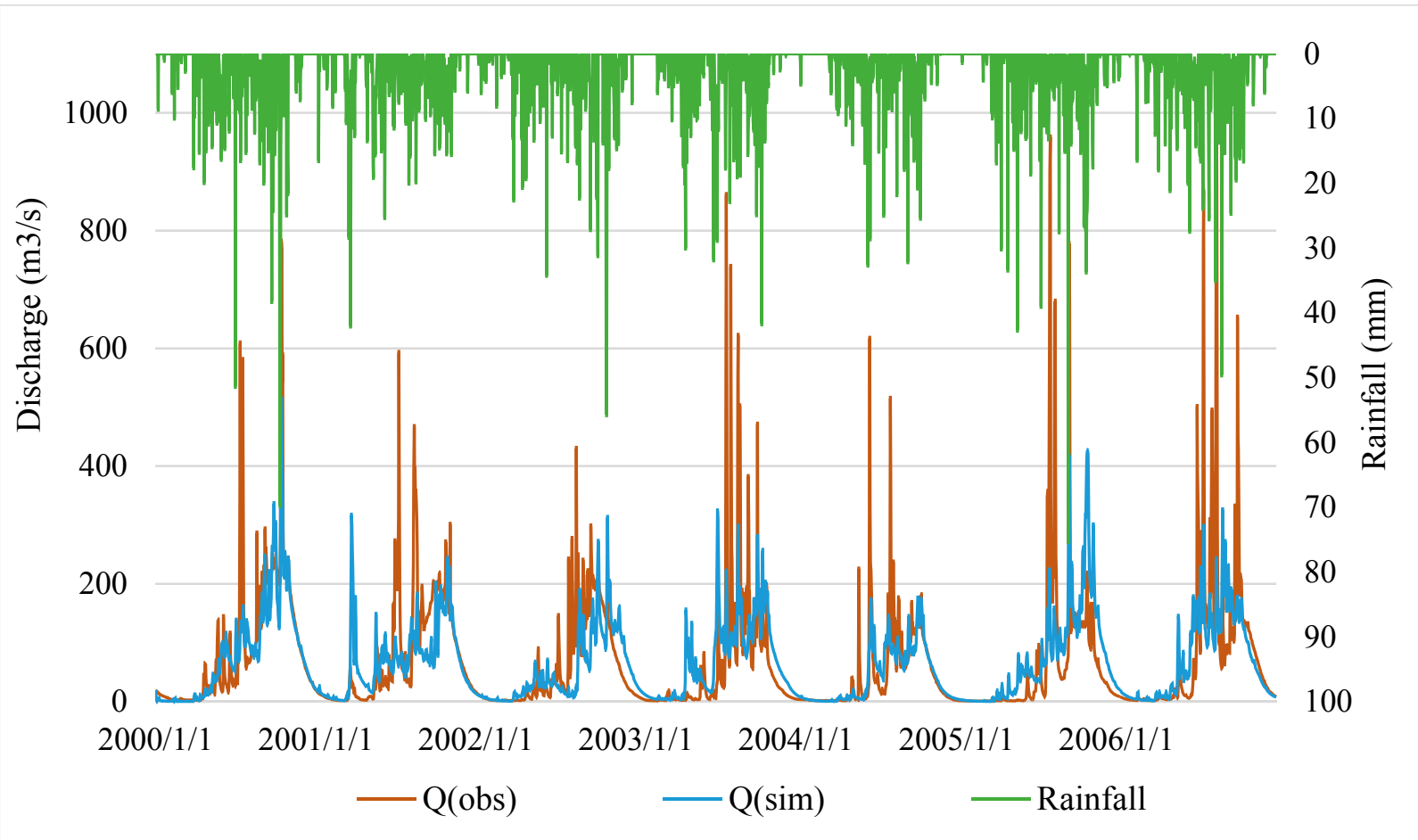

Figure 7. Daily observed and simulated discharge at catchment outlet

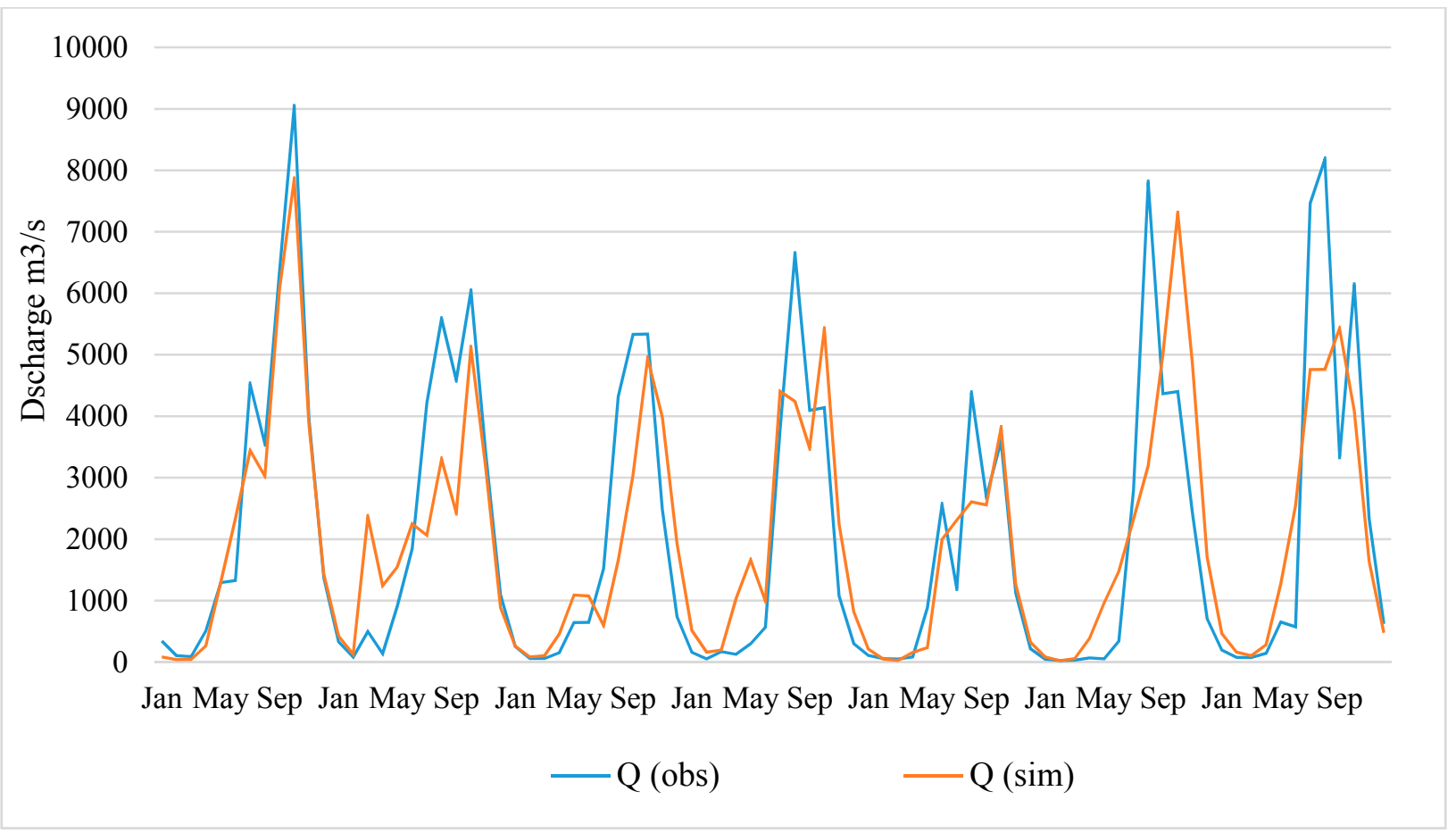

Figure 8. Comparison between monthly observed and simulated discharge

\subsection{Water resources availability of Sub-basin of Stung Sangker basin}

There are 6 selected junctions for studying about the water resources availability in Stung Sangker catchment and the location of each junctions are shown in the Error! Reference source not found.9. As the result found that there are seasonal variation in water resources availability in this basin. In addition, the average annual flow volume of each junctions are 
detailed in Error! Reference source not found.10. The detail of annual flow volume of each junction was shown in Figure 11.

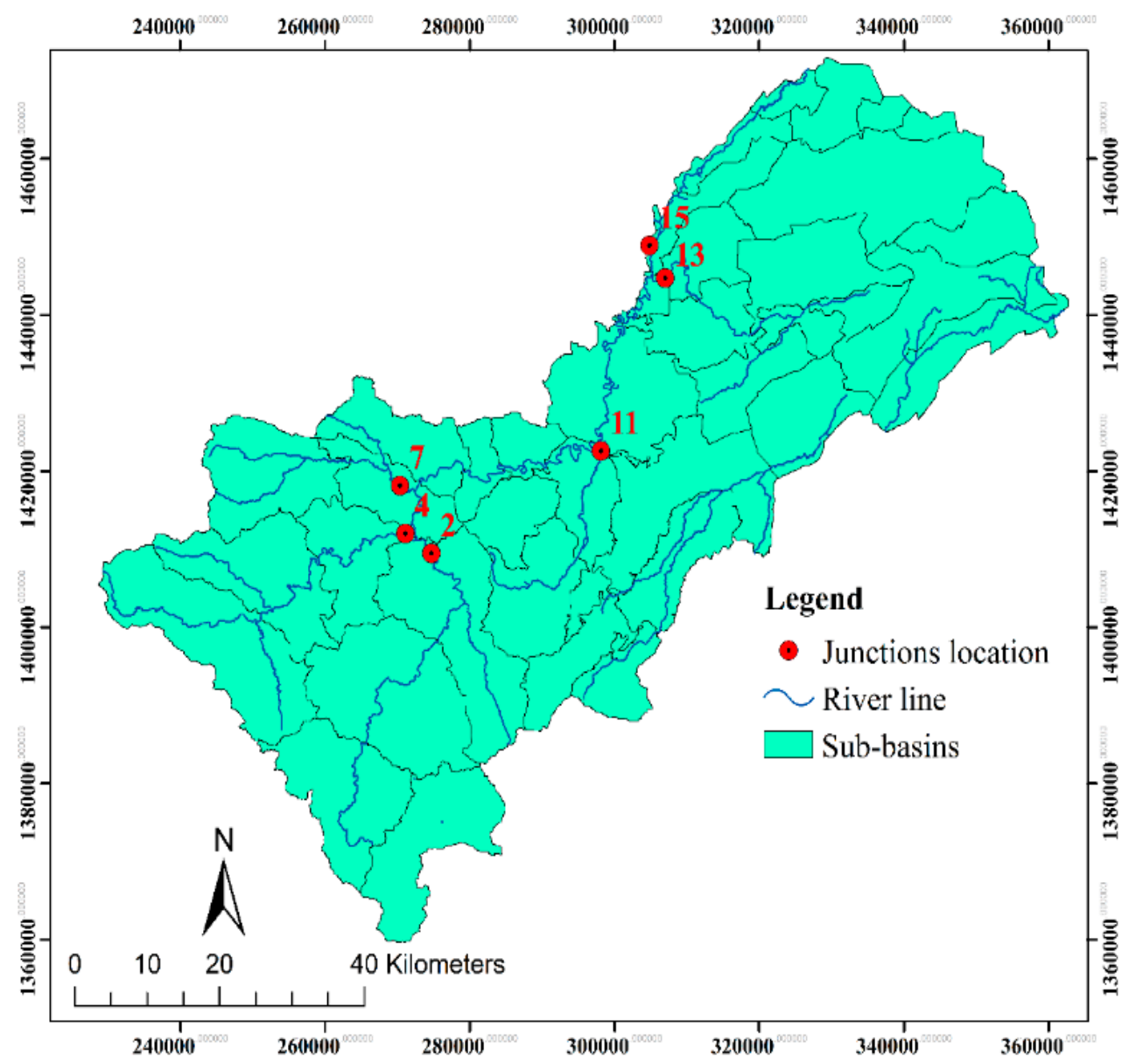

Figure 9. Location of each junctions 
Junction 2
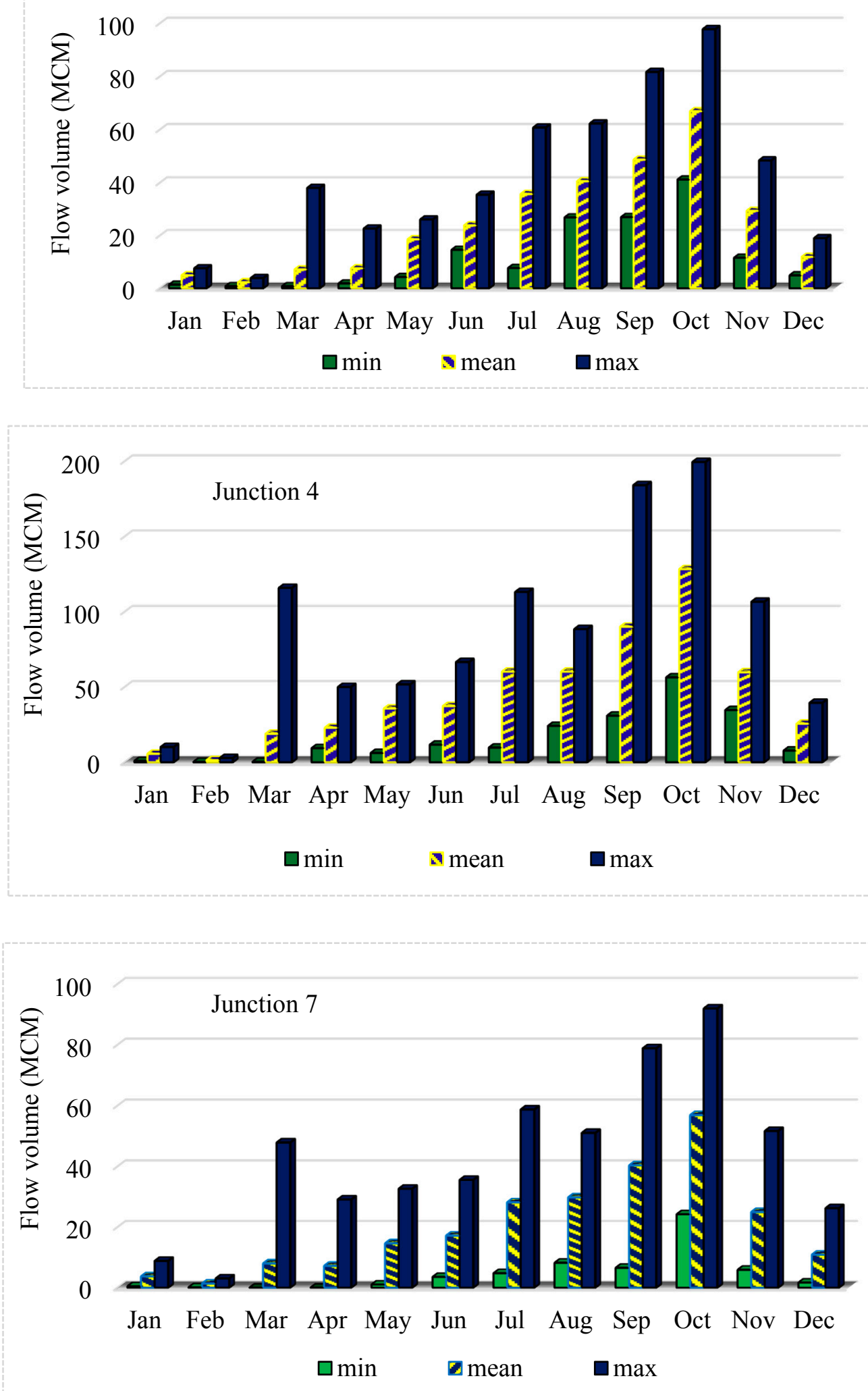

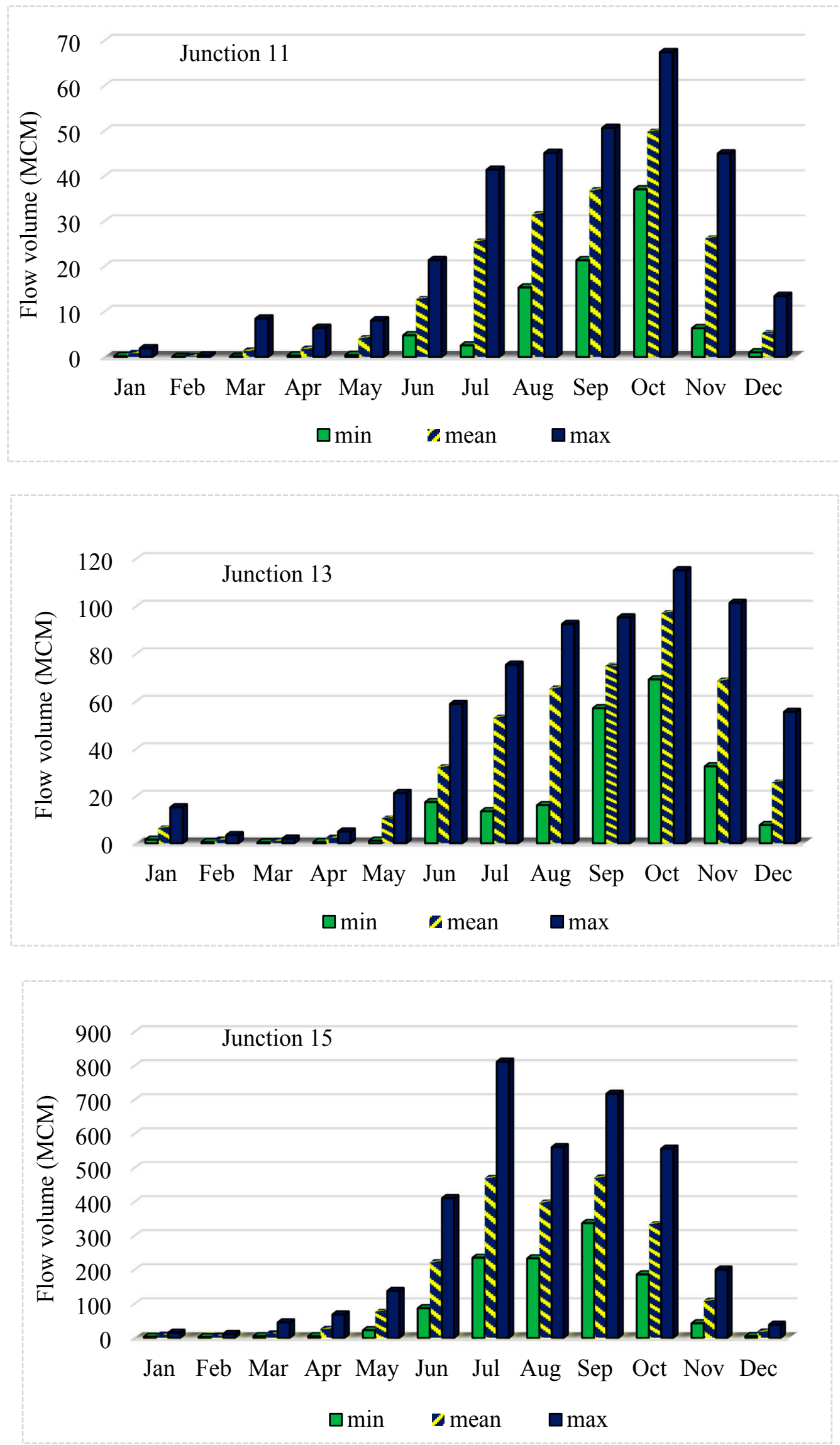

Figure 70. Average monthly flow volume in Junction 2, 4, 7, 11, 13 and 15 


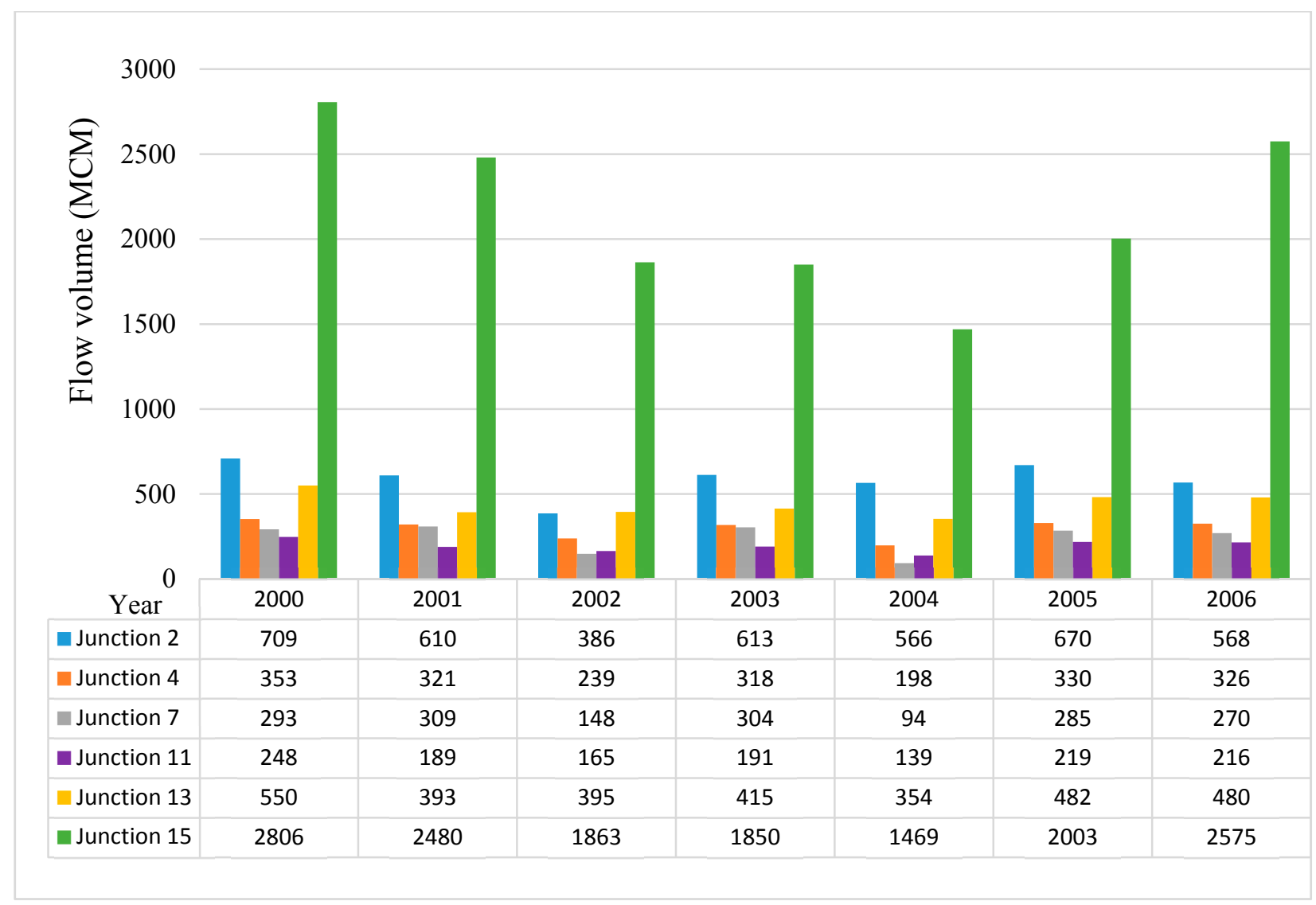

Figure 81. Annual flow volume of each junctions in each years

\subsection{Flow duration curve analysis}

A flow duration curve (FDC) represents the relationship between the magnitude and frequency of daily stream flow for a particular river basin, providing an estimate of the percentage of time a given streamflow was equaled or exceeded over a historical period (Vogel and Fennessey, 1994). An FDC provides a simple, yet comprehensive, graphical view of the overall historical variability associated with streamflow in a river basin. The shape of the flow duration curve for any river strongly reflects the type of flow regime and is influenced by the characteristics of the upstream catchment including geology, urbanization, artificial influences and groundwater. Therefore, to build the FDC, the flow rates were plotted against the percentage of exceedance scale as illustrated in Error! Reference source not found. 2 . If we look at the flow at $0 \%-25 \%$ exceedance, it was over $100 \mathrm{~m}^{3} / \mathrm{s}$; this is a higher flow rate which may lead to extreme events, so the flow is only at or greater than this flow rate for a smaller proportion of the year. If we look at almost $95 \%$ exceedance, it is about 0.1 $\mathrm{m}^{3} / \mathrm{s}$, which is the lowest flow rate record sometimes causing to droughts, so by definition the flow in the river is at this rate or more for $95 \%$ for more time. Understanding the FDC will assist in providing broad knowledge in hydrologic studies like hydropower, water supply, irrigation planning, river and reservoir sedimentation, sustainability of habitats and water withdrawal allocation from the reservoirs. 


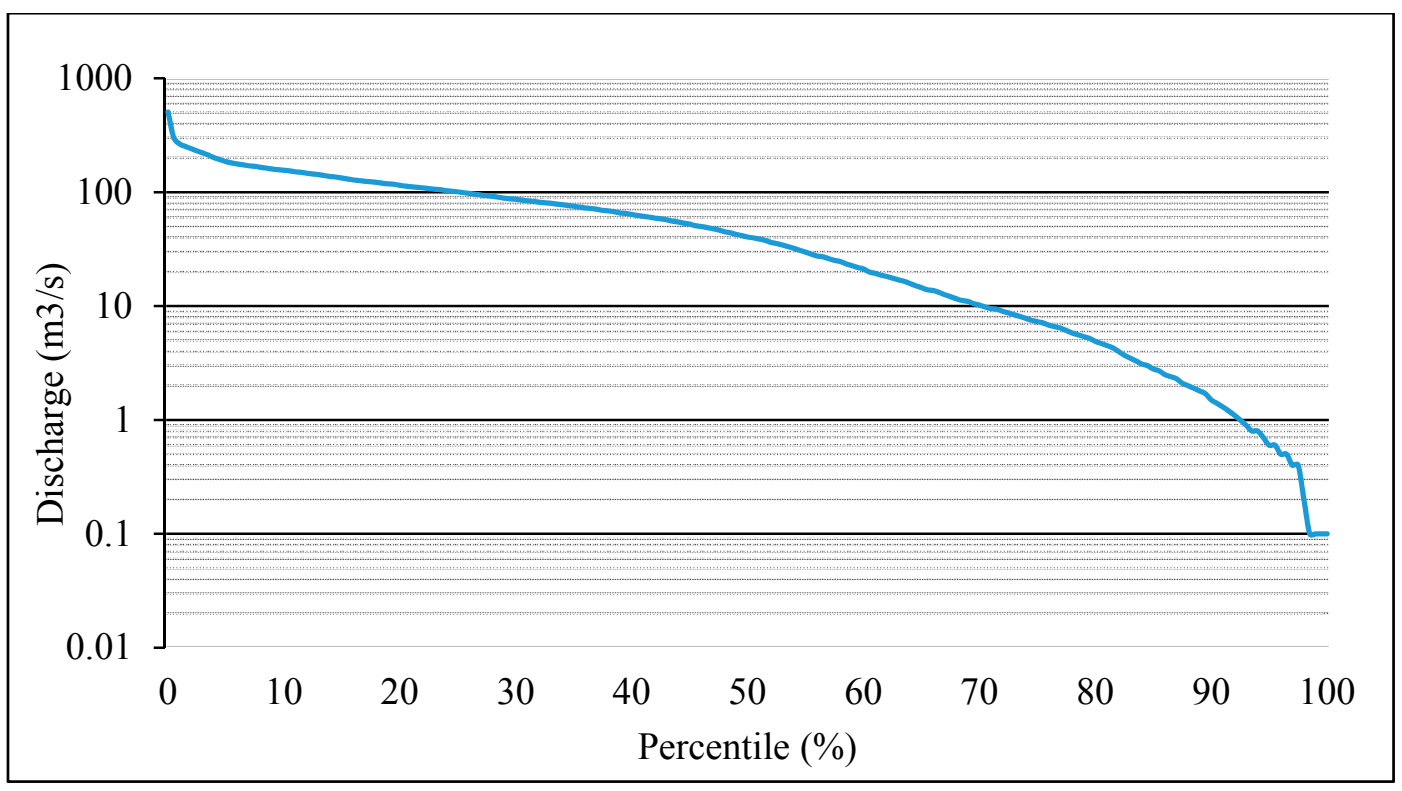

Figure 92. Flow duration curve (2000-2006)

\section{CONCLUSION}

The HEC-HMS conceptual model was used to simulate rainfall runoff in Stung Sangke catchment in Tonlesap Lake Basin with daily time step and analysis into monthly time step. The model performance was given by Nash-Sutcliffe Efficiency criteria followed by 0.44 for daily and 0.71 for monthly basis, respectively. Moreover, the Percent Bias (PBIAS) for daily and monthly simulation was $4.13 \%$ and $3.56 \%$, indicating a satisfactory model fit. The HECHMS conceptual model can be suitably used to simulate flow of Stung Sangke catchment on a continuous time scale particularly monthly basis. The model hand over the water availability in the rivers has been falling down from November to April, but it has slightly gone up and went down in late dry season and start of wet season. The maximum flow volume occurred in October. This case study can be also used as a baseline study for future sustainable water resources planning and management strategy in this Tonlesap Lake catchment. 


\section{ACKNOWLENDMENTS}

Many thanks to Ministry of Water Resources and Meterology of Cambodia for data support. Thank to Mr. Tom Brauer who is the developer of HEC-HMS model for his helpful suggestions with HEC-HMS model.

\section{REFERENCES}

Arekhi, S., 2012. Runoff modeling by HEC-HMS Model (Case Study: Kan watershed, Iran). International Journal of Agriculture and Crop Sciences, 4(23): 1807-1811.

Bansok, R., Chhun, C., Phirun, N., 2011. Agricultural Development and Climate Change: The Case of Cambodia. CDRI. Bennett, T.H., Peters, J.C., 2000. Continuous Soil Moisture Accounting in the Hydrologic Engineering Center Hydrologic Modeling System (HEC-HMS). ASCE Technical Publication.

Choudhari, K., Panigrahi, B., Paul, J.C., 2014. Simulation of rainfall-runoff process using HEC-HMS model for Balijore Nala watershed, Odisha, India. International Journal of Geomatics and Geosciences, 5(2): 253-265.

Chu, X., Steinman, A., 2009. Event and continuous hydrologic modeling with HEC-HMS. Journal of Irrigation and Drainage Engineering, 135(1): 119-124.

Fleming, M., Neary, V., 2004. Continuous hydrologic modeling study with the hydrologic modeling system. Journal of hydrologic engineering, 9(3): 175-183.

Gupta, H.V., Sorooshian, S., Yapo, P.O., 1999. Status of automatic calibration for hydrologic models: Comparison with multilevel expert calibration. Journal of Hydrologic Engineering, 4(2): 135-143.

Halwatura, D., Najim, M., 2013. Application of the HEC-HMS model for runoff simulation in a tropical catchment. Environmental modelling \& software, 46: 155-162.

HEC, 2008. HEC-HMS, User's Manual Version 3.3. Hydrologic Engineering Center California.

MOWRAM, 2015. Pilot Stung Sreng River Basin Plan, Ministry of Water Resources and Meteorology, Cambodia.

NCEP 2015. Globle Weather Data for Swat, Webpage (Issue).

Roy, D., Begam, S., Ghosh, S., Jana, S., 2013. Calibration and validation of HEC-HMS model for a river basin in Eastern India. ARPN Journal of Engineering and Applied Sciences, 8(1): 33-49.

Vogel, R.M., Fennessey, N.M., 1994. Flow-duration curves. I: New interpretation and confidence intervals. Journal of Water Resources Planning and Management, 120(4): 485-504.

Scharffenberg, W.A., Fleming, M.J., 2006. Hydrologic Modeling System HEC-HMS: User's Manual. US Army Corps of Engineers, Hydrologic Engineering Center.

Todini, E., 1996. The ARNO rainfall—runoff model. Journal of Hydrology, 175(1): 339-382.

Yener, M., Sorman, A., Sorman, A., Sensoy, A., 1 Gezgin, T., 2007. Modeling studies with Hec-Hms and runoff scenarios in Yuvacik basin, Turkiye. Int. Congr. River Basin Manage, 4: 621-634.

(C) 2016 by the authors; licensee Preprints, Basel, Switzerland. This article is an open access article distributed under the terms and conditions of the Creative Commons by

Attribution (CC-BY) license (http://creativecommons.org/licenses/by/4.0/). 